ISBN 978-93-84468-80-4

International Conference on Agricultural, Biological and Environmental Sciences

(ICABES-2016)

Pattaya (Thailand) Dec. 14-16, 2016

\title{
Essential Oils: A Viable Control Strategy to Ensure Safe Storage of Food Grains
}

\author{
Shahzad Saleem ${ }^{1}$, Mansoor-U1-Hasan ${ }^{2}$, Qurban $\mathrm{Ali}^{2}$, and Muhammad Sagheer ${ }^{2}$ \\ ${ }^{1}$ Department of Biosciences, COMSATS institute of information technology, Sahiwal, Pakistan \\ ${ }^{2}$ Department of Entomology, University of Agriculture, Faisalabad, Pakistan
}

\begin{abstract}
Stored commodities and their products are subjected to severe infestation due to the deleterious effect of insect pests. This study was designed to evaluate the effectiveness of six essential oils derived from indigenous medicinal plants (i.e., Melia azadirach, Achyranthus aspera, Sasurrea costus, Ferula narthex, Viola odorata and Linium usitatissium) as repellent, contact insecticidal and growth regulators against Tribolium castaneum, a serious pest of stored cereals. The results revealed that highest repellency $91.67 \%$ was observed in case of $M$. azadirach followed by A. aspera (85.00\%) at 15\% concentration. Minimum value of repellency was $35.00 \%$ and that was caused by V. odorata. Mortality was highest (9.30\%) in M. azadirach treatment application, while minimum (0.78\%) in case of A. aspera and that was at par with L. usitatissium (0.78\%). Percent pupation was maximum in case of $V$. odorata and L. usitatissium and was minimum where M. azadirach treatment was done. The highest pupation inhibition was caused by $M$. azadirach oil application. The data showed that adult emergence was highest (98.34\%) in L. usitatissium treatment application and was minimum (36.65\%) in M. azadirach, followed by F. narthex (46.38\%).
\end{abstract}

Keywords: Essential oil, contact toxicity, growth inhibitory, Tribolium castaneum

\section{Introduction}

Insect pests are serious threat to agriculture stored products and their heavy attack results in 10 to $40 \%$ loss annually throughout the world (Rajashekar et al., 2010). In Pakistan, it has been estimated that 5-7\% loss of food grain occurs due to the infestation caused by storage insect pests (Jilani and Ahmad 1982). They make the grains unpalatable and unmarketable due to depletion of specific nutrients (Jood and Kapoor 1994). Tribolium castaneum is very common and most destructive pest of stored products throughout the world and is generally found in granaries, mills, warehouses and stored grains. The presence of this pest in stored products results in contamination, economic damage and also decreases its nutritive value (Pugazhvendon et al., 2009). The red flour beetle not only affects the quality and quantity of grains but it also attacks the germ part of grains (Garcia et al., 2005).

Due to the serious problems of genetic resistance by insect species, pest resurgence (Sousa et al., 2009), residual toxicity, photo toxicity, vertebrate toxicity (Rajendran and Sriranjini, 2008) and with the increasing cost of synthetic products and the current lack of effective pesticides for stored product protection, evaluation of local plants as sources of protectants is very desirable to help farmers use locally available and environmentally friendly products to limit post-harvest losses of their produce (Isman, 2006).

Plant origin products are receiving greater attention as prophylactic measures in various fields (Saraphanchotiwitthayaa and Sripalakitb, 2015) including effectiveness against stored product pests (Lehr, 2010), mainly because of their safety to non-target organisms (Isman, 2006). Essential oils of aromatic plant 
that have insecticidal properties could be considered as alternative insecticides (Talukder, 2006). There are many reviews dealing with the use of plant products in general, against insect pests of stored products (Theou et al., 2013; Zapata and Smagghe, 2010; Amin et al., 2012). These pant derived compounds may act as repellents (Caballero-Gallardo et al., 2011), contact insecticides (Ko et al., 2009b), antifeedants (Ebadollahi, 2011), fumigants (Liska 2010) and may affect some biological parameters such as life span, growth rate and reproduction (Pandey, 2006). Neem tree is one of the most promising botanical insecticides at present. Recently, concentrations as low as $0.01 \%$ protein-rich pea flour ( $P$. sativum) have been shown to cause adult mortality and reduce reproduction in several stored-product insect pests (Fields et al., 2001).

In the light of above said information, present study has been planned to assess the repellent, toxicant and growth regulatory effect of essential oils of six medicinal plants against T. castaneum.

\section{Materials And Methods}

\section{Collection and Rearing of Insects}

Infested grain samples from different locations of Punjab, Pakistan (Longitude $73^{\circ} 74$ East; Latitude $30^{\circ} 31.5$ North; Altitude: $184 \mathrm{~m}$ ), (Longitude, 73-06; Latitude, 30-40 north; Altitude $150 \mathrm{~m}$ ) and (Longitude, $72^{\circ} 08^{\prime}$ to $72^{\circ} 48$; Latitude, $30^{\circ} 33^{\prime}$ to $31^{\circ} 2$ north; Altitude, $162 \mathrm{~m}$ ) were collected and brought to laboratory. Test insect populations of $T$. castaneum were sorted out from the collected samples.

Collected insects were kept in the jars of $9.5 \mathrm{~cm}$ diameter and covered with the muslin cloths. Rearing of the insects was performed in the laboratory for three months to achieve the uniform populations. Insects were regularly checked for their growth and sieved and transferred to jars $(\mathrm{J})$ half filled with fresh wheat flour and yeast (95: 5 by weight). Temperature at $30 \pm 2{ }^{\circ} \mathrm{C}$ and relative humidity at $65 \pm 5 \%$ was maintained for insect maximum growth by using incubator (Model MIR-254, SANYO). Test insects of equal size and age (one week old) from the jars (J) were used for subsequent experiments.

\section{Preparation of Plant Essential Oils}

Plant parts (leaves) of six locally grown medicinal plants i.e. Melia azadirach, Achyranthus aspera, Sasurrea costus, Ferula narthex, Viola odorata and Linium usitatissium were collected from different locations of Faisalabad, Punjab, Pakistan. These fresh plant parts were brought to laboratory of Grain Research, Training and Storage Management Cell, Department of Agri. Entomology, University of Agriculture Faisalabad (Longitude $73^{\circ} 74$ East; Latitude $30^{\circ} 31.5$ North; Altitude: $184 \mathrm{~m}$ ) and dried in shade at room temperature. Dried plant parts were grinded to powder using stone electric grinder (Machine No. 20069, Pascall Engineering Co. Ltd.). Grinded material was then sieved through 40 mesh sieve to obtain fine powder.

\section{Extraction}

Soxhelt extraction apparatus (Model WHM12295, DAIHAN Scientific Co., Ltd.) was used to prepare essential oils. Soxhelt thimble was filled with $50 \mathrm{~g}$ of fine botanical powder and placed in flask. Acetone was used as solvent in bottom flask. This process of extraction oil from all plant powders was repeated to achieve enough quantity of essential oil based on the nature of plant material. Extracted essential oil was purified by evaporating solvent by using electric rotary evaporator. These pure extracted essential oils were preserved in glass vials at $4{ }^{\circ} \mathrm{C}$ to prepare the concentrations of 5,10 and $15 \%$ by mixing acetone as solvent. These concentrations were used for subsequent experiments.

\section{Repellency tests on filter paper}

Area Preference Method was followed for the evaluation of repellant activities of the essential oils (Tapondjou et al., 2005; Olivero et al., 2009; Olivero-Verbel et al., 2010; Caballero et al., 2011). Filter papers of $9 \mathrm{~cm}$ (Whatman No.1) were used as test area after cutting into two equal halves. One half of the filter paper was treated as uniform as possible with $0.5 \mathrm{ml}$ of each concentration $(5,10$ and $15 \%)$ of essential oil and second half was treated with acetone alone $(0.5 \mathrm{ml})$ as control. The filter papers were allowed to air dry for 10 minutes to evaporate the solvent. Both the half filter papers of acetone and essential oil were rejoined to make a full disc using adhesive tape. These treated and re-attached halves were placed in $9 \mathrm{~cm}$ glass petri dish. Twenty test insect from mixed-sex population of T.castaneum (adult) were released at the center of each filter paper disc and covered the petri dishes with lid to overcome the escape of insect. Then petri dishes were kept in incubator at 30 $\pm 2{ }^{\circ} \mathrm{C}$ and at $65 \pm 5 \%$ relative humidity. Three replications were performed for each concentration of essential 
oils. The numbers of test insects present on the untreated and treated portions of the filter paper disc halves were recorded after 24 hours of exposure.

\section{Bioassay for Mortality}

The contact bioassay of essential oils was evaluated by using Filter paper method (Tapondjou et al., 2005). Aliquots of the solutions of the essential oil were applied on the Whatman No 1 Filter papers. 5, 10 and $15 \%$ of concentrations of essential oil were used. Control was treated with acetone alone. Treated filter papers were be kept in air and allowed to evaporate the solvent (acetone) for $10 \mathrm{~min}$. Treated filter papers were placed in glass Petri dishes and 20 test insects were released in each Petri dish. These Petri dishes were closed with glass lid and sealed with plastic tape to prevent the insects from escape. The Petri dishes were kept in incubator (Model MIR254, SANYO) at $25 \pm 2{ }^{\circ} \mathrm{C}$ and $65 \pm 5 \%$ relative humidity. Number of dead insects was recorded after 3 days of treatment.

\section{Bioassay for Growth Inhibitory Effects of essential Oils}

Wheat grains for $\mathrm{T}$. granarium were treated with $2 \mathrm{ml}$ of different concentrations $(5,10$ and $15 \%)$ of each essential oil. Acetone alone was used as control. Treated samples were allowed to evaporate solvent for $10 \mathrm{~min}$ by keeping them in dry air. Twenty (20) adults of the test insect were released in each jar on treated and untreated diet and allowed to lay eggs for 7 days. Jars were kept in incubator (Model MIR-254, SANYO) at $25 \pm$ $2{ }^{\circ} \mathrm{C}$ and $65 \pm 5 \%$ relative humidity. After 7 days, adults were removed from treatment jars. Data for larval duration, $\%$ pupation, and adult emergence in $F_{1}$ was recorded after every two day interval. Experiment was carried out with three replications.

\section{Statistical analysis:}

The collected data were subjected to the Analysis of Variance (ANOVA) using Statistica software (Stat Soft, 8.0). Significant differences among the treatments were determined by Tukey's HSD tests $(p \leq 0.05)$.

\section{Results}

\section{Repellency}

The repellency result showed that all plants are very effective against $T$. castaneum. The $\%$ repellency increases with increase in the concentrations of the essential oil of plants. The maximum repellency was observed at $15 \%$ concentration. Melia azadirach was proved to be very effective against among all the test plants as shown in table 1. Adults of T. casteneum showed maximum repellency (91.67\%) against M. azadirach at $15 \%$ concentration of essential oil. Achyranthus aspera was the second most effective plant in term of repellency behavior by showing $85.00 \%$ value of mean repellency. Essential oils of other test plants such as Sasurrea costus, Ferula narthex, Viola odorata has also shown repellent effect but it is less as compared to the $M$. azadirach and $A$. aspera. From the result it was concluded that $T$. castaneum was more susceptible to essential oil of $M$. azadirach. Essential oil of $L$. usitatissium proves to be least effective against target insect. The order of effectiveness of essential oils of plants on the basis of repellent effect was $M$. azadirach $>A$. aspera $>S$. costus $>$ F. narthex $>V$. odorata $>$ L. usitatissium.

TABLE I Mean comparison of the data regarding repellency of Tribolium castaneum at different concentrations of six plant essential oils

\begin{tabular}{|c|c|c|c|c|c|c|}
\hline \multirow{2}{*}{$\begin{array}{c}\text { Concentrations } \\
(\%)\end{array}$} & \multicolumn{6}{|c|}{ Repellency (\%) } \\
\hline & $\begin{array}{c}\text { M. } \\
\text { azadirach }\end{array}$ & $F$. narthex & S. costus & A. aspera & V. odorata & $\begin{array}{c}L . \\
\text { usitatissium }\end{array}$ \\
\hline 15 & $91.67 \pm 1.67 \mathrm{a}$ & $66.66 \pm 1.66 \mathrm{a}$ & $78.57 \pm 1.43 \mathrm{a}$ & $85.00 \pm 1.68 \mathrm{a}$ & $53.33 \pm 1.46 \mathrm{a}$ & $73.33 \pm 1.95 \mathrm{a}$ \\
\hline 10 & $\begin{array}{c}82.33 \pm 1.45 \\
b\end{array}$ & $57.66 \pm 1.45 \mathrm{a}$ & $66.33 \pm 1.85 \mathrm{a}$ & $\begin{array}{c}75.66 \pm 1.20 \\
b\end{array}$ & $\begin{array}{c}43.00 \pm 1.35 \\
\mathrm{ab}\end{array}$ & $61.66 \pm 0.87 \mathrm{ab}$ \\
\hline 5 & $74.33 \pm 0.73 \mathrm{c}$ & $\begin{array}{c}48.33 \pm 0.89 \\
\mathrm{~b}\end{array}$ & $56.46 \pm 0.81 b$ & $66.66 \pm 1.54 \mathrm{c}$ & $\begin{array}{c}35.00 \pm 1.42 \\
\mathrm{~b}\end{array}$ & $52.33 \pm 1.20 \mathrm{~b}$ \\
\hline
\end{tabular}




\section{Mortality}

The mortality results revealed that some plants have insecticidal properties (Table 2). Maximum mortality was caused by $M$. azadirach followed by $F$. narthex. The maximum mean mortality shown by $M$. azadirach at $15 \%$ concentration of essential oil was 9.30\%. Maximum mortality of target insect was observed at $15 \%$ concentration of essential oil. The result reveals that mortality increases with increase in the concentration of essential oil. The $F$. narthex has also shown insecticidal properties but it was less effective than M. azadirach. Four plants $M$. azadirach, $F$. narthex, $S$. costus, A. aspera has shown insecticidal properties against the target insects.

TABLE II Mean comparison of the data regarding percent mortality of Tribolium castaneum at various concentrations of essential oils of six medicinal plants

\begin{tabular}{ccccccc}
\hline $\begin{array}{c}\text { Concentrations } \\
(\%)\end{array}$ & \multicolumn{5}{c}{ Mortality (\%) } \\
\cline { 2 - 7 } & M. azadirach & F. narthex & S. costus & A. aspera & V. odorata & L. usitatissium \\
$\mathbf{1 5}$ & $9.30 \pm 1.20 \mathrm{a}$ & $8.21 \pm 1.13 \mathrm{a}$ & $7.84 .1 .14 \mathrm{a}$ & $4.87 \pm 0.80 \mathrm{a}$ & $4.12 \pm 0.78 \mathrm{a}$ & $2.64 \pm 0.81 \mathrm{a}$ \\
$\mathbf{1 0}$ & $6.35 \pm 1.24 \mathrm{ab}$ & $4.87 \pm 1.32 \mathrm{~b}$ & $4.12 \pm 0.42 \mathrm{a}$ & $2.64 \pm 0.69 \mathrm{~b}$ & $1.89 \pm 0.57 \mathrm{~b}$ & $1.89 \pm 0.56 \mathrm{a}$ \\
$\mathbf{5}$ & $3.38 \pm 0.87 \mathrm{c}$ & $2.64 \pm 0.87 \mathrm{~b}$ & $1.52 \pm 0.58 \mathrm{~b}$ & $0.78 \pm 0.57 \mathrm{~b}$ & $1.15 \pm 0.58 \mathrm{~b}$ & $0.78 \pm 0.57 \mathrm{a}$ \\
\hline
\end{tabular}

\section{Growth regulatory}

Studies on the \% pupation, \% adult emergence for $T$. castaneum was done. The results show that all plants are effective in inhibiting the percent pupation and adult emergence in T. castaneum (Table 3). Melia azadirach was again most effective among all tested plants. The treatment in which maximum concentration of essential oil of $M$. azadirach was used against $T$. castaneum has shown considerable reduction in $\%$ pupation and $\%$ larval emergence. The \% pupation from grubs of Tribolium castaneum due to application of essential oil of $M$. azadirach was $52.50 \%$ at $15 \%$ concentration while it was $81.26 \%$ at $5 \%$ concentration of essential oil. From results it was revealed that $\%$ pupation considerably decrease with increase in the concentration of the essential oil of M. azadirach.

TABLE III Mean comparison of the data regarding pupation (\%) of Tribolium castaneum at different concentrations of six plant essential oils

\begin{tabular}{|c|c|c|c|c|c|c|}
\hline \multirow{2}{*}{$\begin{array}{c}\text { Concentrations } \\
(\%)\end{array}$} & \multicolumn{6}{|c|}{ Pupation (\%) } \\
\hline & M. azadirach & F. narthex & S. costus & A. aspera & V. odorata & L. usitatissium \\
\hline 15 & $52.50 \pm 1.43 \mathrm{a}$ & $61.64 \pm 1.68 \mathrm{a}$ & $75.05 \pm 0.67 \mathrm{a}$ & $68.34 \pm 1.78 \mathrm{a}$ & $76.34 \pm 1.65 \mathrm{a}$ & $81.53 \pm 1.06 \mathrm{a}$ \\
\hline 10 & $66.63 \pm 1.65 \mathrm{~b}$ & $75.00 \pm 0.83 b$ & $80.12 \pm 0.83 b$ & $76.35 \pm 1.46 b$ & $81.56 \pm 1.38 \mathrm{a}$ & $90.04 \pm 0.94 \mathrm{~b}$ \\
\hline 5 & $81.26 \pm 1.52 \mathrm{c}$ & $83.54 \pm 1.56 \mathrm{c}$ & $86.76 \pm 1.27 \mathrm{c}$ & $86.56 \pm 1.60 \mathrm{c}$ & $93.47 \pm 1.24 b$ & $94.62 \pm 0.86 c$ \\
\hline Control & $93.35 \pm 1.64 \mathrm{~d}$ & $93.24 \pm 1.38 \mathrm{~d}$ & $95.14 \pm 0.98 \mathrm{~d}$ & $95.86 \pm 0.72 \mathrm{~d}$ & $100.00 \pm 0.08 \mathrm{~d}$ & $100.00 \pm 0.00 \mathrm{~d}$ \\
\hline
\end{tabular}

Essential oil of seeds of $F$. narthex was also quite effective in retarding growth of grubs of $T$. castaneum as \%pupation and \% adult emergence in grubs of $T$. castaneum has considerably reduce due to the application of the maximum concentration of essential oil of $F$. narthex (Table 4). The other four tested plants viz $A$. aspera, S. costus, V. odorata, L. usitatissium has shown good results in reducing $\%$ pupation and $\%$ adult emergence which were significantly differed from control treatments.

TABLE IV Mean comparison of the data regarding percent adult emergence of Tribolium castaneum at various concentrations of six plant essential oils

\begin{tabular}{|c|c|c|c|c|c|c|}
\hline \multirow[t]{2}{*}{ Concentrations (\%) } & \multicolumn{6}{|c|}{ Adult Emergence (\%) } \\
\hline & M. azadirach & F. narthex & S. costus & A. aspera & V. odorata & L. usitatissium \\
\hline 15 & $36.65 \pm 1.34 \mathrm{a}$ & $46.38 \pm 1.83 \mathrm{a}$ & $71.67 \pm 1.53 \mathrm{a}$ & $58.65 \pm 1.16 \mathrm{a}$ & $71.24 \pm 1.12 \mathrm{a}$ & $83.62 \pm 1.42 \mathrm{a}$ \\
\hline 10 & $53.27 \pm 1.08 \mathrm{~b}$ & $63.481 .02 \mathrm{~b}$ & $81.56 \pm 1.34 b$ & $73.62 \pm 1.76 \mathrm{~b}$ & $83.67 \pm 1.36 \mathrm{~b}$ & $88.54 \pm 1.06 \mathrm{ab}$ \\
\hline 5 & $65.12 \pm 1.06 \mathrm{c}$ & $71.76 \pm 1.24 \mathrm{c}$ & $88.74 \pm 0.86 \mathrm{c}$ & $82.13 \pm 0.56 \mathrm{c}$ & $88.46 \pm 0.76 \mathrm{c}$ & $93.28 \pm 0.87 \mathrm{bc}$ \\
\hline Control & $90.32 \pm 0.84 \mathrm{~d}$ & $90.26 \pm 0.82 \mathrm{~d}$ & $95.13 \pm 0.76 \mathrm{~d}$ & $95.31 \pm 0.74 \mathrm{~d}$ & $95.08 \pm 0.84 \mathrm{~d}$ & $98.34 \pm 0.54 \mathrm{c}$ \\
\hline
\end{tabular}




\section{Discussion}

The essential oils and their constituents have proved the potential to replace conventional insecticides and have shown to be promised as natural insect pest control agents (Dorman and Deans, 2000; Bakkali et al., 2008; Saleem et al., 2014). Some of these compounds show acute toxicity against insects while others may have phago deterrent, repellent, fumigant, growth and reproduction or development inhibition or may interact with biochemical and physiological insect processes (Lehr, 2010). Current study was also designed to evaluate properties of some indigenous medicinal plant essential oils as agriculture stored grain protectant.

From the above results it was concluded that all the six plants M. azadirach, F. narthex, A. aspera, S. costus, $V$. odorata and L. usitatissium, had significant adverse effect on $T$. castaneum. In context of repellency $M$. azadirach was found most effective repellent with $91.67 \%$ followed by A. aspera (85.0\%), S. costus (78.57\%), L. usitatissium $(73.33 \%), F$. narthex $(66.66 \%)$ and $V$. odorata $(53.33 \%)$ on $15 \%$ of concentration. These results are in line with earlier report (Saljoqi et al., 2006) in which M. azadirach exhibited maximum repellency of $72 \%$ on $10 \%$ of concentration after $24 \mathrm{hr}$ against Sitophilus oryzae. Current study resulted in little higher repellency of $M$. azadirach at $10 \%$ concentration $(82.33 \%)$ which may be because of different insect tested. All tested essential oils significantly killed the tested insects but $M$. azadirach was found the most effective contact insecticide. These results also stand in accordance with some previous reports (Said and Assad, 2004; Manzoor et al., 2011).

Tested essential oils also reduced insect pupation significantly. Pupation was reduced to $52.5 \%$ with the application of $15 \%$ concentration of $M$. azadirach. L. usitatissium was observed as least effective pupation inhibitor essential oil among tested essential in which even with the application of $15 \%$ concentration $81.53 \%$ insects were pupated. Findings of this research are in accordance with earlier documentation (Anita et al., 2012) which reported considerable decreased larval emergence in $T$. castaneum when treated with some plant essential oils. Similar results were documented in another study Jbilou et al. (2006) evaluated essential oils of $A$. iva, $R$. vaphanistrum, Ari baetica and P. harmala against different developmental stages of $T$. castaneum and observed that adult emergence reduced by all essential oils tested i.e., percentage emergence inhibition of A. iva, Ari baetica and $R$. vaphanistrum was $98.56,98.58$ and 98.66 respectively.

Results of current study showed that all essential oils used remarkably repel, kill and reduced growth $T$. castanium. This make them useful stored product insect pest protectant however many factors influence their efficiency i.e. concentration. This factor has also been investigated in some earlier studies (Ogendo et al., 2008; Sattar et al., 2010; Mishra and Tripathi, 2011). Treatments with low concentrations resulted in less efficacy in all experiments which was found to be increased with increase in concentration to $15 \%$. Similar trend was observed by some earlier scientific studies Pugazhvendan et al. (2012) reported more repellency on $5 \%$ concentration than $2.5 \%$. Indirect relationship of concentration and pupal emergence was also confirmed by former study Haghighian et al. (2008) evaluated growth regulatory effects of Artemisia annua against $T$. confusum and adult emergence was reduced from 92.5 to 33.75 with increase in concentration from $200 \mu 1 / 1$ to $1600 \mu 1 / 1$.

\section{References}

[1] Amin R, Mondol R, Rahman F, Alam J, Habib R, Hossain T (2012) Evaluation of insecticidal activity of three plant extracts against adult Tribolium castaneum (Herbst). BIOLOGIJA 58, 37-41.

https://doi.org/10.6001/biologija.v58i2.2484

[2] Anita S, Sujatha P, Prabhudas P (2012) Efficacy of pulverised leaves of Annona squamosa (L.), Moringa oleifera (Lam.) and Eucalyptus globulus (Labill.) against the stored grain pest, Tribolium castaneum (Herbst.) Recent Res. Sci. and Tech 4(2), 19-23.

[3] Bakkali F, Averbeck S, Averbeck D, Idaomar M (2008) Biological effects of essential oils review. Food Chem. Toxicol 46, 446-75. https://doi.org/10.1016/j.fct.2007.09.106

[4] Caballero-Gallardo K, Olivero-Verbel J, Stashenko E (2011) Repellent activity of essential oils and some of their individual constituents against Tribolium castaneum Herbst. J. Agri. Food Chem 59, 1690-96. https://doi.org/10.1021/jf103937p

[5] Caballero-Gallardo K, Olivero-Verbel J, Stashenko E (2011) Repellent activity of essential oils and some of their individual constituents against Tribolium castaneum Herbst. J. Agri. Food Chem 59, 1690-96. 
https://doi.org/10.1021/jf103937p

[6] Dorman HJD, Deans SG (2000) Antimicrobial agents from plants, antibacterial activity of plant volatile oils. J. Appl. Microbiol 88, 308-16.

https://doi.org/10.1046/j.1365-2672.2000.00969.x

[7] Ebadollahi A (2011) Antifeedant activity of essential oils from Eucalyptus globulus Labill and Lavandula stoechas L. on Tribolium castaneum Herbst (Coleoptera, Tenebrionidae). Biharean Biologist 5, 8-10.

[8] Fields PG, Xie YS, Hou X (2001) Repellent effect of pea (Pisum sativum) fractions against stored product insects. J. Stored Prod. Res 37, 359-370.

https://doi.org/10.1016/S0022-474X(00)00038-2

[9] Garcia M, Donadel OJ, Ardanaz CE, Tonn CE, Sosa ME (2005) Toxic and repellent effects of Baccharis salicifolia essential oil on Tribolium castaneum. Pest Manag. Sci 61, 612-18.

https://doi.org/10.1002/ps.1028

[10] Haghighian F, Sendi JJ, Aliakbar A, Ashti MJ (2008) The growth regulatory, deterrency and ovicidal activity of worm wood (Artemisia annua L.) on Tribolium confusum Duv. and identification of its chemical constituents by GC-MS. Pestycydy 2, 51-59.

[11] Isman MB (2006) Botanical insecticides, deterrents and repellents in modern agriculture and an increasingly regulated world. Ann. Rev. Entomol 51, 45-66.

https://doi.org/10.1146/annurev.ento.51.110104.151146

[12] Isman MB, Machial CN (2006) Pesticides based on plant essential oils, From traditional practice to commercialization. In RAI M. and C.M. CARPINELLA (Eds.) Naturally Occurring Bioactive Compounds. Amsterdam, Elsevier. p 29-44.

https://doi.org/10.1016/S1572-557X(06)03002-9

[13] Jbilou R, Ennabil A, Sayah F, (2006) Insecticidal activity of four medicinal plant extracts against Tribolium castaneum (Herbst) (Coleoptera, Tenebrionidae). Afr. J. Biotechnol 5(10), 936-40.

[14] Jilani G, Ahmad H (1982) Safe storage of wheat at farm level. Progressive Farming 2(2), 11-15.

[15] Jood S, Kapoor AC (1994) Vitamins contents of cereal grains as affected by storage and insect infestation. Plant Foods and Human Nutrition 46, 237-43. https://doi.org/10.1007/BF01088996

[16] Ko K, Juntarajumnong W, Chandrapatya A (2009b) Repellency, fumigant and contact toxicities of Melaleuca cajuputi Powell against Sitophilus zeamais Motschulsky and Tribolium castaneum Herbst. Thai J. Agri. Sci 42, 27-33.

[17] Lehr PS (2010) Biopesticides, the global market ed. BCC Res, Febr. http,//bccresearch.com/report/ biopesticidesmarket-chm029c.html

[18] Liska A, Rozman V, Kalinovic I, Ivezic M, Balicevic R (2010) Contact and fumigant activity of 1,8-cineole, eugenol and camphor against Tribolium castaneum (Herbst). 10th International Working Conference on Stored Product Protection.

[19] Manzoor F, Nasim G, Saif S, Malik SA (2011) Effect of ethanolic plant extracts on three storage grain pests of economic importance. Pak. J. Bot 43(6), 2941-46.

[20] Mishra BB, Tripathi SP (2011) Repellent activity of plant derived essential oils against Sitophilous oryzae (Linnaeus) and Tribolium castaneum (Herbst). Singapore J. Sci. Res 1, 173-78. https://doi.org/10.3923/sjsres.2011.173.178

[21] Ogendo J, Kostyukovsky M, Ravid U, Matasyoh J, deng A, Omolo E, Kariuki S, Shaaya E (2008) Bioactivities of Ocimum gratissimum L.oil and two of its constituents against five insect pests attacking stored food products. $J$. Stored Prod. Res 44, 328-34. https://doi.org/10.1016/j.jspr.2008.02.009

[22] Olivero J, Caballero K, Jaramillo B, Stashenko E (2009) Actividad repelente de los aceites esenciales de Lippiaoriganoides, Citrus sinensis, y Cymbopogon nardus cultivadas en Colombia frente a Tribolium castaneum, Herbst. Salud UIS 41, 244-50.

[23] Olivero-Verbel J, Nerio LS, Stashenko EE (2010) Bioactivity against Tribolium castaneum Herbst (Coleoptera, Tenebrionidae) of Cymbopogon citratus and Eucalyptus citriodora essential oils grown in Colombia. Pest Manag. Sci 66, 664-668. 
[24] Pandey V, Kumar N, Tripathi NN (2006) The growth regulatory, deterrency and ovicidal activityof worm wood (Artemisia annua L.) on Tribolium confusum Duv. and identification of its chemical constituents by GC-MS. Botanica 56, 119-24.

[25] Pugazhvendan SR, Ross PR, Elumalai K (2012) Insecticidal and Repellant Activities of Four indigenous medicinal plants against stored grain pest, Tribolium castaneum (Herbst) (Coleoptera,Tenebrionidae). Asian Paci. J. Trop. Dise. S16-S20. https://doi.org/10.1016/s2222-1808(12)60116-9

[26] Pugazhvendon SR, Elumalai K, Ross PR, Soundararagan M (2009) Repellent activity of chosen plant species against Tribolium castaneum. World J. Zool 4, 188-90.

[27] Rajashekar Y, Gunasekaran N, Shivanandappa T (2010) Insecticidal activity of the root extract of Decalepis hamiltonii against stored product insect pests and its application in grain protection. J Food Sci. Technol 43(3), 31014. https://doi.org/10.1007/s13197-010-0049-6

[28] Rajendran S, Sriranjini V (2008) Plant products as fumigants for stored-product insect control. J. Stored Prod. Res 44, 126-35.

[29] Said MK, Assad AM (2004) Effect of bakain (Melia azadarach) and ak (Calatropis procera) against lesser grain borer "Rhyzopertha dominica F". J. res. Sci 15(3) 319-24

[30] Saleem S, hasan M, Sagheer M, Sahi ST (2014) Insecticidal activity of essential oils of four medicinal plants against different stored grain insect pests. Pak. J. Zool 46(5) 1407-14.

[31] Saljoqi AUR, Munir KA, Shah AK, Sadur R (2006) Effects of six plant extracts on rice weevil Sitophilus oryzae L. In the stored wheat grains. J. Agri. Bio. Sci 1, 1-5.

[32] Saraphanchotiwitthayaa A, Sripalakitb P (2015) Anti-inflammatory activity of a Vernonia cinerea methanolic extract in vitro. ScienceAsia 41, 392-99. https://doi.org/10.2306/scienceasia1513-1874.2015.41.392

[33] Sattar EA, Ahmed AZ, Mohamed AF, Sabah HEG, Fathalla MHH (2010) Chemical composition, insecticidal and insect repellent activity of Schinus molle L. leaf and fruit essential oils against Trogoderma granarium and Tribolium castaneum. Nat. Prod. Res 24, 226-35. https://doi.org/10.1080/14786410802346223

[34] Sousa A, Faroni L, Pimentel M, Guedes R (2009) Developmental and population growth rates of phosphine-resistant and susceptible populations of stored product insect pests. J. Stored Prod. Res 45, 241-46.

[35] StatSoft, Inc. 2008. STATISTICA (data analysis software system), version 8.0. www.statsoft.com.

[36] Talukder FA (2006) Plant products as potential stored -product insect management agents - A mini review. Emir. J. Food Agric 18(1), 17-32. https://doi.org/10.9755/ejfa.v12i1.5221

[37] Tapondjou AL, Alder C, Fontem DA, Bouda H, Reichmuth C (2005) Bioactivities of cymol and essential oils of Cupressus sempervirens and Eucalyptus saligna against Sitophilus zeamais Motschulsky and Tribolium confusum du Val. J. Stored Prod. Res 41, 91-102. https://doi.org/10.1016/j.jspr.2004.01.004

[38] Theou G, Papachristos DP, Stamopoulos DC (2013) Fumigant toxicity of six essential oils to the immature stages and adults of Tribolium confusium. Hellenic Plant Prot. J 6, 29-39.

[39] Zapata N, Smagghe G (2010) Repellency and toxicity of essential oils from the leaves and bark of Laurelia sempervirens and Drimys winteri against Tribolium castaneum. Ind. Crops and Prod 32, 405-10. https://doi.org/10.1016/j.indcrop.2010.06.005 